\title{
Hormonalna terapia zastępcza - czy droga podania ma znaczenie?
}

\author{
Joanna Tkaczuk-Włach ${ }^{1}$, Małgorzata Sobstyl ${ }^{1}$, Rafał Włach², Grzegorz Jakiel ${ }^{3}$ \\ ${ }^{1}$ Katedra i Klinika Ginekologii i Endokrynologii Ginekologicznej, Uniwersytet Medyczny w Lublinie; \\ kierownik Katedry i Kliniki: prof. dr hab. n. med. Lechosław Putowski \\ ${ }^{2}$ Katedra i Zakład Zdrowia Publicznego, II Wydział Lekarski z Oddziałem Anglojęzycznym, Uniwersytet Medyczny w Lublinie; \\ kierownik Katedry i Kliniki: prof. dr hab., dr h.c. mult. Piotr Książek \\ ${ }^{3}$ Klinika Położnictwa i Ginekologii, CMKP w Warszawie; \\ kierownik Kliniki: prof. dr hab. n. med. Grzegorz Jakiel
}

Przegląd Menopauzalny 2013; 6: 504-508

\section{Streszczenie}

W czasie ostatniej dekady jesteśmy świadkami dramatycznych zmian w poglądach na temat terapii hormonalnej okresu menopauzy. Po dokonaniu reanalizy wyników badania WHI (Women's Health Initiative) stało się jasne, że ryzyko i korzyści wynikające z jej zastosowania różnią się u kobiet w okresie okołomenopauzalnym w stosunku do tych, które okres przejściowy mają już za sobą. Niniejszy artykuł skupia się na korzyściach wynikających z przezskórnej drogi aplikowania hormonów w tym okresie.

Słowa kluczowe: terapia hormonalna okresu menopauzy, droga przezskórna, estradiol, progestageny, żylna choroba zakrzepowo-zatorowa.

\section{Summary}

The past decade has seen dramatic change in opinions of the menopausal hormonal therapy (MHT). After the re-analysis of the WHI (Women's Health Initiative) results it becomes clear that the risk and benefits of MHT differ for women during the menopause transition compared to those for older women. This paper focused on the benefits of the transdermal route of hormone administration.

Key words: menopausal hormonal therapy, transdremalroute, estradiol, progestogens, venous thromboembolism.

Rozwój wspótczesnej medycyny niezaprzeczalnie jest bardzo dynamiczny. Wpływa na to wiele czynników, w tym postęp wiedzy medycznej i innych kierunków nauki, ale również szereg nowych problemów natury epidemiologicznej i demograficznej, którym dzisiejsza medycyna musi sprostać.

Bardzo istotnym wyzwaniem jest obecnie opieka nad ludźmi w późnym wieku dojrzałym, szczególnie kobietami w okresie klimakterium. Ten dziat medycyny, nazywany coraz powszechniej „opieką menopauzalną”, obejmuje szczególny okres w życiu kobiety. Najczęściej jest to czas trudny dla kobiety zarówno fizycznie, jak i psychicznie ze względu na zachodzące $w$ jej organizmie zmiany wynikające $z$ ustania funkcji jajników. $Z$ drugiej strony w dzisiejszej rzeczywistości społecznej nie jest to czas odchodzenia na tzw. boczny tor. W życiu zawodowym, jak również rodzinnym kobieta podlega nadal presji podejmowania wielu wyzwań życia codziennego. Dodatkowo dochodzą często problemy zdrowotne najbliższych członków rodziny - w tym potrzeba zapewnienia opieki dużo starszym już rodzicom.

Liczba kobiet szukających fachowej i kompleksowej pomocy $w$ okresie okołomenopauzalnym nie będzie spadać. Wręcz odwrotnie, długość życia się wydłuża, a potrzeby dotyczące utrzymania jego jakości na satysfakcjonującym poziomie wzrastają. Wychodząc naprzeciw tym potrzebom, liczne towarzystwa medyczne zajmujące się problemami okresu menopauzy wydały szereg opinii i rekomendacji dotyczących postępowania i leczenia kobiet w tym okresie życia.

Zasadniczym celem terapii hormonalnej jest uzupełnienie $w$ okresie okołomenopauzalnym niedoboru estrogenów i zniwelowanie przez to licznych niekorzystnych objawów, tzw. objawów wypadowych [1]. Zasadą jest, że u kobiet z zachowaną macicą suplementacja hormonalna powinna obejmować obok estrogenów

Adres do korespondencji:

Joanna Tkaczuk-Włach, Katedra i Klinika Ginekologii i Endokrynologii Ginekologicznej UM w Lublinie, Al. Racławickie 23, 20-037 Lublin 
progestageny, stosowane przez 12-14 dni w cyklu, jako profilaktyka przerostów i raka endometrium [2, 3].

Szczególnie istotną kwestią dotyczącą opieki okołomenopauzalnej jest bezpieczeństwo stosowanej terapii. Wyniki publikowanych w ostatnich latach badań wskazują jednoznacznie na istotnie wyższy profil bezpieczeństwa terapii przezskórnej w porównaniu ze stosowaną wcześniej nagminnie terapią doustną. Można powiedzieć, że terapia przezskórna przeżywa obecnie swój renesans. W niniejszym artykule zostaną omówione korzyści wynikające z jej stosowania.

W ostatnim roku z inicjatywy Międzynarodowego Towarzystwa Menopauzy (The International Menopause Society) doszło do spotkania przedstawicieli czołowych regionalnych towarzystw naukowych zajmujących się menopauzą: American Society for Reproductive Medicine, Asia Pacific Menopause Federation, Endocrine Society, European Menopause and Andropause Society (EMAS), International Menopause Society, International Osteoporosis Foundation i North American Menopause Society (NAMS).

Owocem tego spotkania było opublikowanie dokumentu zawierającego współczesną wiedzę i akceptowane przez wszystkich zalecenia dotyczące hormonalnej terapii menopauzalnej [4].

Kwestią bezsporną pozostaje potrzeba indywidualizacji menopauzalnej terapii hormonalnej (MTH) pod względem czasu jej rozpoczęcia, drogi podania i długości czasu stosowania. Eksperci jeszcze raz podkreślili wagę dokładnego wywiadu rodzinnego i osobistego oraz konieczność oszacowania indywidualnego ryzyka związanego z zakrzepicą żylną, chorobą niedokrwienną serca, udarem niedokrwiennym czy rakiem piersi.

Stosowana dawka i czas trwania terapii również powinny podlegać indywidualnym wskazaniom wynikającym z obecności objawów wypadowych i potrzebie bezpieczeństwa terapii [1, 4].

Co do drogi podania autorzy podkreślają bezpieczeństwo terapii transdermalnej szczególnie w odniesieniu do ryzyka rozwoju choroby zakrzepowo-zatorowej oraz udaru niedokrwiennego. Jednocześnie wskazują na fakt wzrostu ryzyka dla powyższych zdarzeń w czasie stosowania terapii doustnej, jednak w grupie kobiet poniżej 60. roku życia określają je jako zdecydowanie rzadkie [4].

Aplikacja drogą przezskórną uważana jest obecnie za istotną alternatywę dla stosowanej terapii doustnej. Większość towarzystw naukowych zajmujących się menopauzą w opublikowanych w ostatnich latach rekomendacjach podkreśla zalety przezskórnej terapii w ramach hormonalnej terapii zastępczej. Podkreśla się jej wysoki profil bezpieczeństwa, nawet $w$ grupach kobiet obciążonych czynnikami ryzyka, wysoką skuteczność wynikającą ze stabilnego i długotrwałego stężenia substancji czynnych w surowicy pacjentki. Nie bez znaczenia jest również wygoda stosowania tej formy terapii wynikająca z prostej jej aplikacji [3-5].
Polski zespół ekspertów pod auspicjami Polskiego Towarzystwa Menopauzy i Andropauzy wydał również bardzo wyczerpujący dokument poświecony zaleceniom i sposobom dobierania drogi podania hormonów. Autorzy, porównując drogę wchłaniania i metabolizm hormonów, stwierdzają, że doustna i przezskórna MTH [...] sa $w$ zasadzie dwiema zupetnie różnymi metodami terapii $[6,7]$. Tak zwany efekt pierwszego przejścia $17 \beta$-estradiolu przez wątrobę, towarzyszący terapii doustnej, ogranicza jego biodostępność i wpływa istotnie na szereg funkcji metabolicznych organizmu. Są to m.in. wzrost stężenia estronu $\left(E_{1}\right)$ i jego siarczanu oraz wzrost wątrobowej syntezy białka wiążącego hormony płciowe (sex hormone-binding globulin - SHGB). Tymczasem podczas terapii transdermalnej, dzięki ominięciu metabolizmu wątrobowego, możliwa jest redukcja dawki estrogenu oraz względnie stały dostęp do czynnego i stabilnego stężenia hormonu $[6,8]$. Taki stan warunkuje również inny wpływ na funkcje metaboliczne i w rezultacie inne efekty terapeutyczne.

Autorzy polscy i zagraniczni opisują szereg sytuacji, w których indywidualny wywiad i dobranie m.in. drogi terapii pozwala w sposób optymalny „skroić na miarę” terapię menopauzalną, tak aby ograniczyć możliwe efekty uboczne do minimum.

Najbardziej istotnym powikłaniem MTH budzącym obawy zarówno lekarzy, jak i pacjentek ze względu na zagrożenie życia pozostają zaburzenia hemostazy w układzie żylnym i wzrost ryzyka rozwoju żylnej choroby zakrzepowo-zatorowej (ŻChZZ) oraz zatorowości płucnej.

Menopauza jest okresem, który niesie ze sobą szereg niekorzystnych zmian w układzie żylnym kobiety. Należą do nich m.in. zwolnienie przepływu w układzie żylnym, niekorzystne zmiany $w$ funkcjonowaniu śródbłonka, np. uwalnianie czynnika aktywującego płytki (platelet activating factor - PAF), ekspozycja integryn i selektyn na powierzchni komórek zorientowanej wewnątrznaczyniowo, synteza czynnika tkankowego (tissue factor - TF). Wreszcie potwierdzono szereg zmian w układzie hemostazy podnoszących ryzyko rozwoju ŻChZZ u kobiet pomenopauzalnych, tj. zwiększenie stężenia fibrynogenu, wzrost aktywacji trombocytów, czynnika VII, IX, homocysteiny, lipoproteiny a, inhibitora aktywacji plazminogenu 1, a zmniejszenie stężenia tkankowego aktywatora plazminogenu (tissue plazminogen activator - t-PA) [6, 9].

W przypadku zastosowania doustnej terapii menopauzalnej zmiany te mogą się dodatkowo nasilać. W czasie jej trwania następuje zwiększenie stężenia czynnika VII, wzrost D-dimerów czy zmniejszenie stężenia t-PA. Podobnych zmian w koagulogramie nie stwierdzono w przypadku kobiet stosujących terapię przezskórną $[6,10]$.

Uważa się, że doustna MTH zwiększa ryzyko wystąpienia ŻChZZ 2-4-krotnie, z największym ryzykiem w pierwszym roku jej stosowania. Ma to szczególne 
znaczenie $u$ kobiet otyłych [ze wskaźnikiem masy ciała (body mass index - BMI) $>30 \mathrm{~kg} / \mathrm{m}^{2}$ ], u których wyjściowe ryzyko rozwoju ŻChZZ jest samo w sobie zwiększone 3-krotnie [3, 11, 12].

Ryzyko zachorowania na ŻChZZ podnoszą dodatkowe indywidualne czynniki ryzyka, tj. obciążony wywiad rodzinny, przebyta zakrzepica żylna, zaawansowany wiek, otyłość, żylaki kończyn dolnych lub przewlekła niewydolność żylna, wrodzona trombofilia, zabieg chirurgiczny czy przewlekła hospitalizacja połączona z unieruchomieniem [13, 14].

W dużym kanadyjskim badaniu z udziałem 955582 kobiet, u pacjentek stosujących tibolon oraz terapię przezskórną zarówno samym estradiolem (estrogen therapy - ET), jak i z dodatkiem progestagenów (estradiolprogestagen therapy - EPT) nie stwierdzono wzrostu ryzyka rozwoju ŻChZZ. Nie zauważono wzrostu ryzyka zakrzepicy w odniesieniu do dawki stosowanego przezskórnie estrogenu (za małą uznawano dawkę $\leq 50 \mu \mathrm{g}$, za dużą $50 \mu$ g estrogenu). Odwrotny efekt, czyli wzrost ryzyka, zanotowano $w$ trakcie stosowania terapii doustnej - był on zależny i proporcjonalny do wzrostu dawki stosowanego estrogenu. Dodatkowo zaobserwowano szczególnie istotny wzrost ryzyka w pierwszym roku terapii. Ten niekorzystny efekt zanikał po 4 miesiącach od zaprzestania leczenia $[9,15]$.

Badano również wpływ drogi podania na wzrost ryzyka powtórnego wystąpienia ŻChZZ i stwierdzono brak wpływu przezskórnej terapii estrogenowej (w porównaniu z terapią doustną i placebo) na ryzyko nawrotów zakrzepicy żylnej u kobiet z wywiadem obciążonym wystąpieniem w przeszłości tego schorzenia [16].

Inną determinantą bezpieczeństwa - w odniesieniu do ryzyka rozwoju ŻChZZ - w trakcie stosowania transdermalnej formy terapii okresu menopauzalnego wydaje się rodzaj stosowanego w niej progestagenu.

Przez długi czas skupiano się raczej na estrogenach i ich roli w podwyższaniu ryzyka wystąpienia ŻChzZ, tymczasem temat roli progestagenów był dość marginalizowany.

Pojawiały się jednak analizy, które niezależnie od badania WHI (Women's Health Initiative) wskazywały, że ryzyko rozwoju ŻChZZ wzrasta w grupie kobiet, u których dodawane są progestageny w porównaniu z grupą stosującą same estrogeny $[17,18]$.

W innym dużym badaniu WIDSOM (Women's International Study of long Duration Oestrogen after Menopause) kobiety stosujące estrogeny skoniugowane w połączeniu z medroksyprogesteronem (MPA) były w grupie wyższego ryzyka rozwoju zakrzepicy w porównaniu ze stosującymi same estrogeny, jednak różnice te nie okazały się statystycznie istotne [19].

Medroksyprogesteron jest $\mathrm{w}$ zasadzie wiodącym progestagenem stosowanym w Stanach Zjednoczonych u kobiet w okresie menopauzy i po niej. W Europie gama stosowanych $w$ tym okresie progestagenów jest istot- nie bogatsza. Najprawdopodobniej stało się to jednym z pretekstów do podjęcia we Francji badań nad wpływem rodzaju terapii złożonej na ryzyko rozwoju ŻChZZ.

Opublikowane wyniki powyższych badań określanych akronimem ESTHER (EStrogen and THromboEmbolism Risk) wskazują że mikronizowany progesteron i pochodne pregnanu mogą być bezpieczniejsze niż pochodne norprogesteronu w odniesieniu do ryzyka rozwoju ŻChZZ.

W innym francuskim badaniu E3N (Etude Epidémiologique de l'Education Nationale) potwierdzono bezpieczeństwo stosowania mikronizowanego progesteronu [20].

Dwa inne badania z randomizacją przyniosły potwierdzenie, że doustne, ale nie transdermalne, zastosowanie estrogenu z mikronizowanym progesteronem indukuje oporność na aktywne białko C, działając prozakrzepowo [21, 22].

W podsumowaniu tematu progestagenów posłuży opinia EMAS z 2011 r., w której eksperci sugerują, że nie tylko droga podania estrogenu, lecz także typ progestagenu ma znaczenie w kontekście zmniejszania ryzyka wystąpienia ŻChZZ [23]. Mikronizowany progesteron oraz dydrogesteron wymaniane są jako te o korzystnym profilu działania w kontekście zmniejszenia ryzyka rozwoju ŻChZZ. Zalecenia europejskich ekspertów wskazują na drogę transdermalną jako metodę z wyboru u kobiet otyłych ze wskazaniami do zastosowania terapii menopauzalnej. W przypadkach wywiadu obciążonego wystąpieniem w przeszłości choroby zakrzepowej lub potwierdzonej mutacji prozakrzepowej zaleca się indywidualne szacowanie ryzyka i rozważenie ewentualnej terapii transdermalnej przy zdecydowanym zakazie stosowania terapii doustnej w tych przypadkach [3, 23].

Stanowisko NAMS z 2012 roku, podobnie jak Ekspertów Polskiego Towarzystwa Menopauzy i Andropauzy, oraz najnowsze zalecenia innych towarzystw zajmujących się problemami menopauzy (Global Consensus 2013) stwierdzają, że mimo braku wystarczająco wiarygodnych badań $z$ randomizacją terapia drogą transdermalną, jak również terapia samymi estrogenami (w porównaniu z EPT) wydaje się bezpieczniejsza w kontekście ryzyka rozwoju ŻChZZ, a ryzyko to jest szczególnie niskie $w$ grupie wiekowej do 60. roku życia $[2,3,4,6]$.

W badaniu WHI (zarówno ramię ET, jak i EPT) wykazano wzrost ryzyka udaru niedokrwiennego przy braku wpływu na częstość występowania udaru krwotocznego.

Ryzyko to jest szczególnie wysokie przy prowadzeniu terapii doustnej u kobiet po 60. roku życia $[6,24]$.

Tymczasem ocena bezpieczeństwa stosowania niskodawkowej terapii transdermalnej w odniesieniu do ryzyka udaru niedokrwiennego jest wysoka [15]. Może mieć na to wpływ kilka czynników, m.in. korzystny wpływ na lipidogram - zwiększenie stężenia cholesterolu frakcji HDL, zmniejszenie frakcji LDL, zmniejszenie - w odróżnieniu do terapii doustnej - stężenia trójglicerydów. Okazuje się, że dobór gestagenu może nasilać 
te korzystne zmiany. W polskim badaniu wykazano obniżenie całkowitego cholesterolu i LDL cholesterolu po 3 miesiącach stosowania dopochwowej terapii mikronizowanym progesteronem obok transdermalnej drogi aplikacji estradiolu [25, 26].

Przezskórna droga aplikacji estradiolu nie kojarzy się z wpływem na czynniki prozapalne. Nie odnotowano podczas jej trwania wzrostu stężenia białka C-reaktywnego kojarzonego powszechnie ze wzrostem ryzyka choroby wieńcowej. Odwrotnie, zanotowano zmniejszenie stężeń interleukiny 7 i 8, MCP-1 czy białka zapalnego makrofagów $1 \beta$ [27].

Stwierdzanego podczas doustnej aplikacji estrogenów wzrostu aktywności układu renina-angiotensynaaldosteron (RAA), nie obserwuje się podczas stosowania plastrów. Przy użyciu tych ostatnich kreowana jest więc sytuacja sprzyjająca obniżeniu ciśnienia tętniczego przez optymalne wykorzystanie działania wazodylatacyjnego estrogenów $[1,6]$.

W podsumowaniu należy przytoczyć wspólną opinię Polskiego Towarzystwa Ginekologicznego, Polskiego Towarzystwa Kardiologicznego oraz Polskiego Towarzystwa Menopauzy i Andropauzy: zastosowanie MTH, szczególnie droga przezskórna, w okresie okołomenopauzalnym lub wczesnym pomenopauzalnym, nie podnosi ryzyka wystapienia u nich chorób układu sercowo-naczyniowych, a może działać kardioprotekcyjnie [6].

Na podstawie wyników badań Zespół Ekspertów Polskiego Towarzystwa Menopauzy i Andropauzy podkreśla dodatkowe atuty stosowania terapii transdermalnej.

Korzystne zmiany w wydzielaniu i eliminacji insuliny sprawiają, że coraz częściej terapię przezskórną w okresie menopauzy postrzega się jako profilaktykę rozwoju cukrzycy insulinoniezależnej. Dzięki ominięciu etapu przejścia leków przez wątrobę, terapia transdermalna nie zaburza funkcji układu pokarmowego, nie promuje rozwoju kamicy żółciowej. W przypadku kobiet palących droga przezskórna daje szansę na istotny efekt terapeutyczny, który może być istotnie zredukowany w czasie terapii doustnej. Ponadto wykazano w tej grupie pacjentek korzystniejszą odpowiedź naczyniową w postaci m.in. spadku oporu naczyniowego czy lepkości krwi [1].

W świetle przytoczonych wcześniej faktów i opinii wielu gremiów eksperckich należy zauważyć, że optymalizacja terapii okresu menopauzy musi uwzględniać indywidualizację nie tylko wskazań, rodzaju, czasu terapii czy zastosowanej dawki. Wybór drogi podania hormonów wydaje się w świetle najnowszych badań szczególnie istotny i ma zdecydowany wpływ na bezpieczeństwo ich stosowania. Zgodnie ze stanowiskiem polskich ekspertów, transdermalna forma MTH charakteryzuje się korzystniejszym niż doustna profilem bezpieczeństwa i powinna być terapia $z$ wyboru dla dużej populacji kobiet $z$ dolegliwościami klimakterycznymi [6].

\section{Piśmiennictwo}

1. Bińkowska M, Jakiel G. Terapia hormonalna okresu menopauzy przezskórna droga podania. Prz Menopauz 2012; 16: 281-6.

2. Panay N, Hamoda H, Arya R et al. The 2013 British Menopause Society \& Women's Health Concern recommendations on hormone replacement therapy. Menopause Int 2013; 19: 59-68.

3. North American Menopause Society. The 2012 hormone therapy position statement of: The North American Menopause Society. Menopause 2012; 19: 257-71.

4. de Villiers TJ, Gass ML, Haines CJ, et al. Global consensus statement on menopausal hormone therapy. Climacteric 2013; 16: 203-4.

5. Sturdee DW, Pines A; International Menopause Society Writing Group, et al. Updated IMS recommendations on postmenopausal hormone therapy and preventive strategies for midlife health. Climacteric 2011; 14: 302-20.

6. Dębski R, Paszkowski T, Pertyński T i wsp. Czy wybór drogi podawania hormonów w terapii menopauzalnej ma znaczenie dla jej bezpieczeństwa? Stanowisko Zespołu Ekspertów Polskiego Towarzystwa Menopauzy i Andropauzy. Prz Menopauz 2012; 16: 161-7.

7. Pertyński T, Stachowiak G. Przezskórna terapia okresu menopauzy state of art. 2010. Prz Menopauz 2010; 14: 71-7.

8. Yilmazer M, Fenkci V, Fenkci S, et al. Hormone replacement therapy, $\mathrm{C}$-reactive protein, and fibrinogen in healthy postmenopausal women. Maturitas 2003; 46: 245-53.

9. Stachowiak G. Terapia hormonalna okresu menopauzy a żyły - czy jest się czego bać? Prz Menopauz 2013;17: 52-6.

10. Vehkavaara S, Silveira A, Hakala-Ala-Pietilä T, et al. Effects of oral and transdermal estrogen replacement therapy on markers of coagulation, fibrinolysis, inflammation and serum lipids and lipoproteins in postmenopausal women. Thromb Haemost 2001; 85: 619-25.

11. Heiss G, Wallace R, Anderson GL, et al.; WHI Investigators. Health risks and benefits 3 years after stopping randomized treatment with estrogen and progestin. JAMA 2008; 299: 1036-45.

12. LaCroix AZ, Chlebowski RT, Manson JE, et al. WHI Investigators. Health outcomes after stopping conjugated equine estrogens among postmenopausal women with prior hysterectomy: a randomized controlled trial. JAMA 2011; 305: 1305-14.

13. Høibraaten E, Qvigstad E, Arnesen $\mathrm{H}$, et al. Increased risk of recurrent venous thromboembolism during hormone replacement therapy - results of the randomized, double-blind, placebo-controlled estrogen in venous thromboembolism trial (EVTET). Thromb Haemost 2000; 84: 961-7.

14. Herrington DM, Vittinghoff E, Howard TD, et al. Factor V Leiden, hormone replacement therapy, and risk of venous thromboembolic events in women with coronary disease. Arterioscler Thromb Vasc Biol 2002; 22: 1012-7.

15. Renoux C, Dell'aniello S, Garbe E, Suissa S. Transdermal and oral hormone replacement therapy and the risk of stroke: a nested case-control study. BMJ 2010; 340: c2519.

16. Olié V, Plu-Bureau G, Conard J, et al. Hormone therapy and recurrence of venous thromboembolism among postmenopausal women. Menopause 2011; 18: 488-93.

17. Curb JD, Prentice RL, Bray PF, et al. Venous thrombosis and conjugated equine estrogen in women without a uterus. Arch Intern Med 2006; 166: $772-80$.

18. Cushman M, Kuller LH, Prentice R, et al. Women's Health Initiative Investigators. Estrogen plus progestin and risk of venous thrombosis. JAMA 2004; 292: 1573-80.

19. Vickers MR, MacLennan AH, Lawton B, et al. WISDOM group. Main morbidities recorded in the women's international study of long duration oestrogen after menopause (WISDOM): a randomised controlled trial of hormone replacement therapy in postmenopausal women. BMJ 2007; 335: 239.

20. Canonico M, Fournier A, Carcaillon L, et al. Postmenopausal hormone therapy and risk of idiopathic venous thromboembolism: results from the E3N cohort study. Arterioscler Thromb Vasc Biol 2010; 30: 340-5.

21. Oger E, Alhenc-Gelas M, Lacut K, et al. Differential effects of oral and transdermal estrogen/progesterone regimens on sensitivity to activated protein $C$ among postmenopausal women: a randomized trial. Arterioscler Thromb Vasc Biol 2003; 23: 1671-6. 
22. Post MS, Christella M, Thomassen LG, et al. Effect of oral and transdermal estrogen replacement therapy on hemostatic variables associated with venousthrombosis: a randomized, placebo-controlled stud y in postmenopausal women. Arterioscler Thromb Vasc Biol 2003; 23: 1116-21.

23. Tremollieres F, Brincat M, Erel CT, et al. European Menopause and Andropause Society. EMAS position statement: Managing menopausal women with a personal or family history of VTE. Maturitas 2011; 69: 195-8.

24. Wassertheil-Smoller S, Hendrix SL, Limacher M, et al. Women's Health Initiative Investigators. Effects of estrogen plus progestin on stroke in the Women's Health Initiative: a randomized trial. Circulation 2006; 113: 2425-34.

25. Paszkowski T. Hormonalna terapia zastępcza oparta na podawaniu 17-beta-estradiolu przezskórnie i mikronizowanego progesteronu - ocena skuteczności i tolerancji. Prz Menopauz 2003; 7: 61-6.

26. Woźniakowska E, Milart P, Woźniak S i wsp. Standardy hormonalnej terapii zastępczej po Women's Health Initiative - przegląd najnowszych doniesień dotyczących znaczenia drogi podania dla profilu bezpieczeństwa terapii. Prz Menopauz 2013; 17: 83-6.

27. Yasui T, Saijo A, Uemura $H$, et al. Effects of oral and transdermal estrogen therapies on circulating cytokines and chemokines in postmenopausal women with hysterectomy. Eur J Endocrinol 2009; 161: 267-73.

Prawidłowe odpowiedzi do Testowego programu edukacyjnego dotyczącego znaczenia drogi podania hormonalnej terapii zastępczej, zamieszczonego w numerze 5/2013 Przeglądu Menopauzalnego:

1. d; 2. d; 3. a; 4. a; 5. d; 6. d; 7. a; 8. d; 9. d; 10. b; 11. d; 12. d; 13. d; 14. d; 15. a. 